\title{
Isoseismals for the Kutch earthquake of 26th January 2001
}

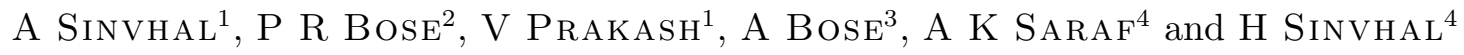 \\ ${ }^{1}$ Department of Earthquake Engineering, Indian Institute of Technology, Roorkee, 247 667, India \\ ${ }^{2}$ Department of Civil Engineering, Delhi College of Engineering, Bawana Road, Delhi 110 042, India \\ ${ }^{3}$ Designers and Planners Combine, AG 5\%, Shalimar Bagh, Delhi, 110 052, India \\ ${ }^{4}$ Department of Earth Sciences, Indian Institute of Technology, Roorkee, 247 667, India
}

\begin{abstract}
Damage observed during the Kutch earthquake of 26th January 2001 is classified according to the type of structure. This damage pattern has been used to draw the isoseismal map on the basis of the intensity scale given in IS 1893-2002 which covers only traditional one to two storey houses. Having thus estimated intensities, and observed damage to other types of structures, a new criterion was adopted which is included in this paper. Areas that showed maximum damage to structures have been assigned maximum intensity $\mathrm{X}$.
\end{abstract}

\section{Introduction}

The isoseismal map (figure 1) for the Kutch earthquake of January 26th, 2001 (m 6.9) was drawn on the basis of a composite damage survey of several kinds of buildings. These included houses in rural and urban areas and reinforced concrete buildings of schools, hospitals, community inns and government offices. The survey also included temples; 46 storey buildings; infrastructure buildings such as overhead water tanks, substations of Gujarat Electricity Board, roads, bridges, industrial buildings and oil installations; and ground damage (Bose et al 2001; Prakash et al 2001 (a,b,c,d,e,f); Saraf et al 2001, 2002; Sinvhal et al 2001 (a,b,c,d,e,f,g) 2002). For each type of structure it was important to judge the quality of construction and the presence of critical deficiencies. No landscape changes, barring soil-liquefaction, were observed anywhere, and therefore the maximum intensity assigned is limited to $\mathrm{X}$.

On the basis of the criteria given in table 1 , intensity values were assigned to different sites (table 2) along with notable structural and ground damage. Table 3 gives the geographical coordinates of the places listed in table 2, most of which are plotted in figure 3. Damage pattern, seismotectonics and isoseismals for the Kutch earthquake of 26th January 2001, suggest that the area of maximum intensity $\mathrm{X}$ was controlled by the complex tectonics of the area. Heavy damage and destruction to multistorey buildings in Ahmedabad (epicentral distance $>250 \mathrm{~km}$ ) and in Surat (epicentral distance $>350 \mathrm{~km}$ ) are attributed to a number of critical deficiencies in design and construction, aggravated by the ground response of soft alluvium of the Cambay basin and rivers. Multistorey buildings in areas of thick alluvium have shown more damage compared to similar buildings in hard rock areas.

Failure of columns occurred at ground storey level in most multistoreyed buildings in Bhachau, Anjar, Gandhidham, Bhuj, Ahmedabad and Surat. In the ground storey of these buildings the walls were not provided for creating parking space. The storeys above had both columns and walls. This caused the ground storey to become weak in comparison to the storeys above and resulted in concentration of damage in the ground storey columns.

\section{Acknowledgements}

Professor and Head, Department of Earthquake Engineering, IIT Roorkee, provided finances to A Sinvhal and V Prakash; and P R Bose was finan-

Keywords. Isoseismal map; MM intensities; damage survey; structures; soft storey; rural houses; urban buildings; collapse. 

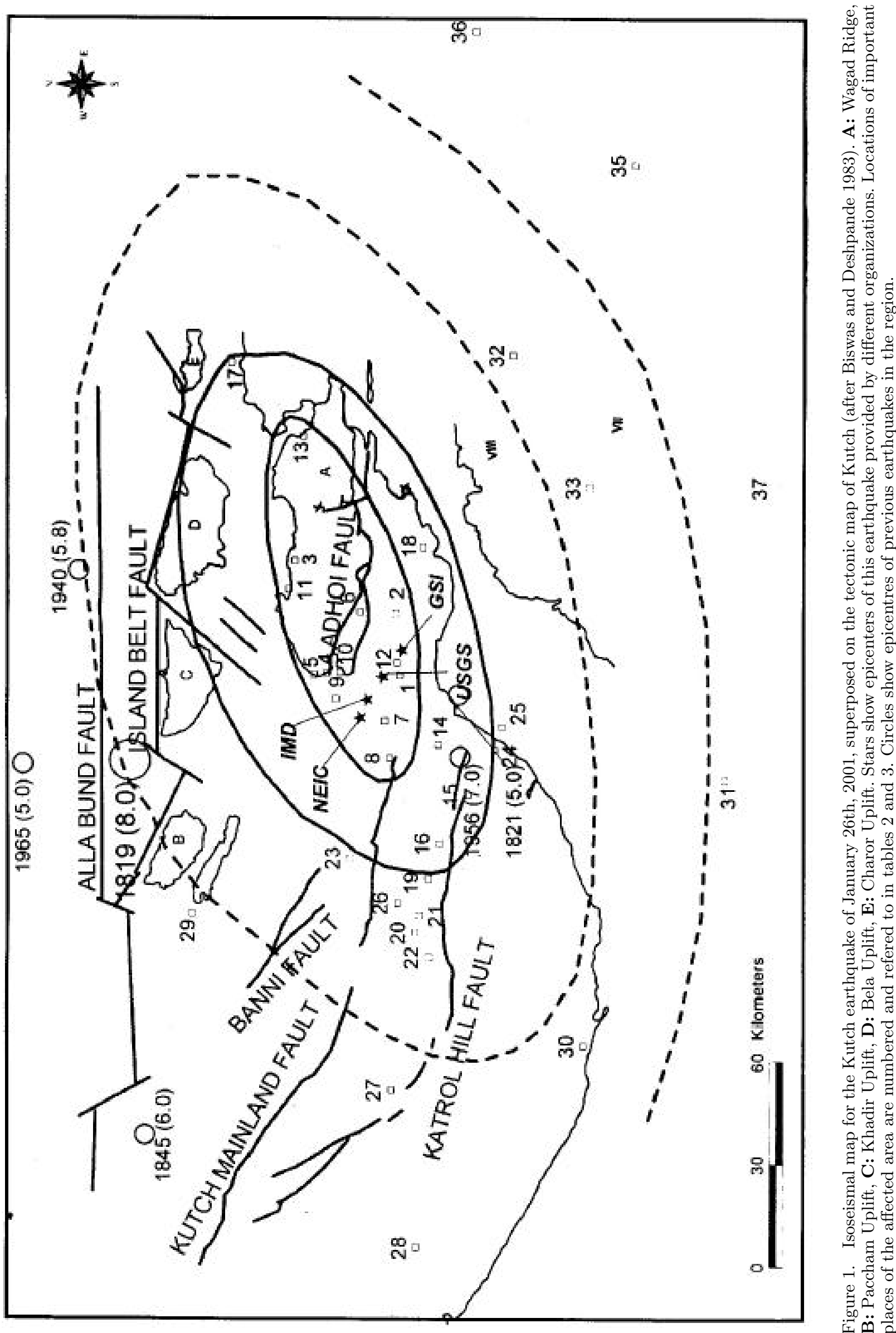


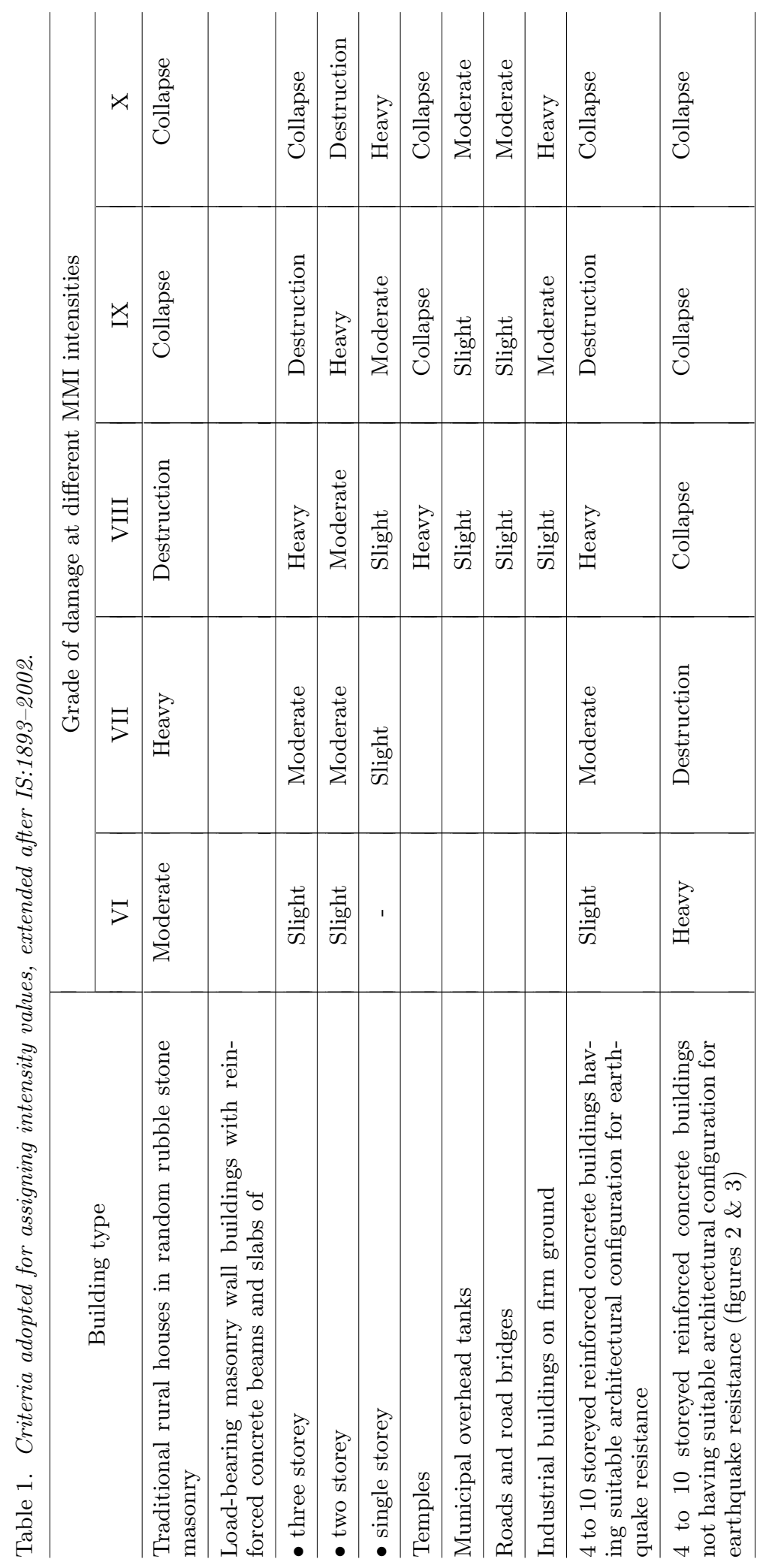




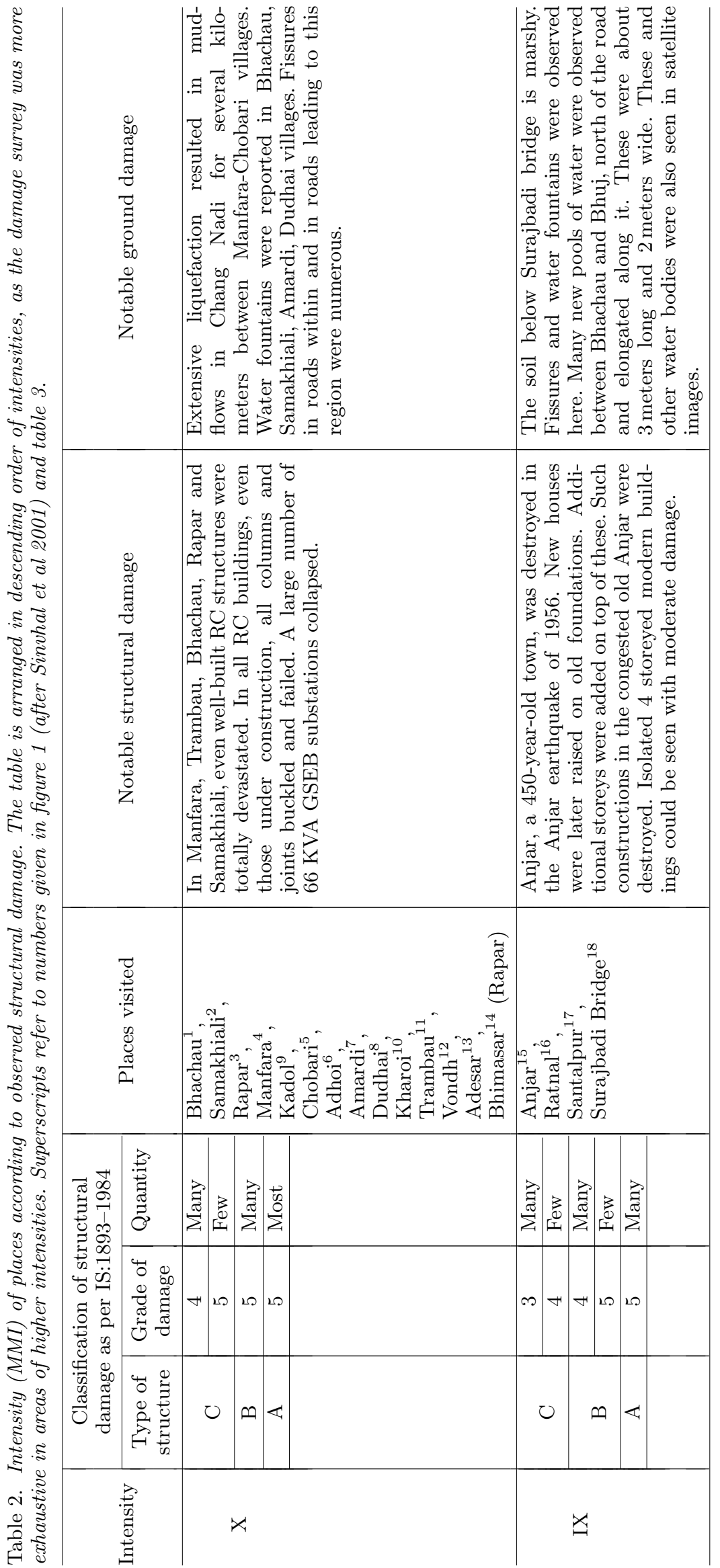




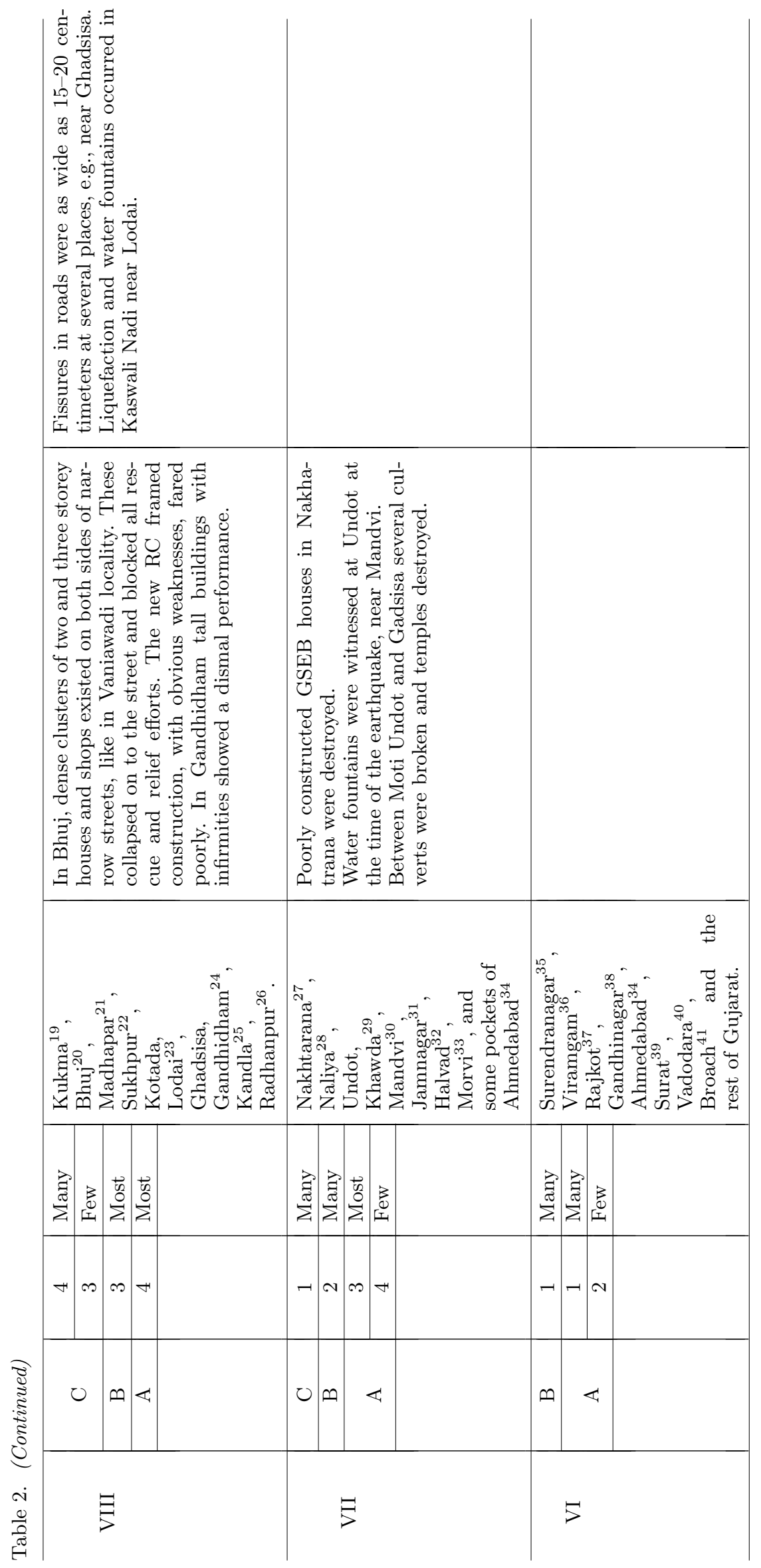



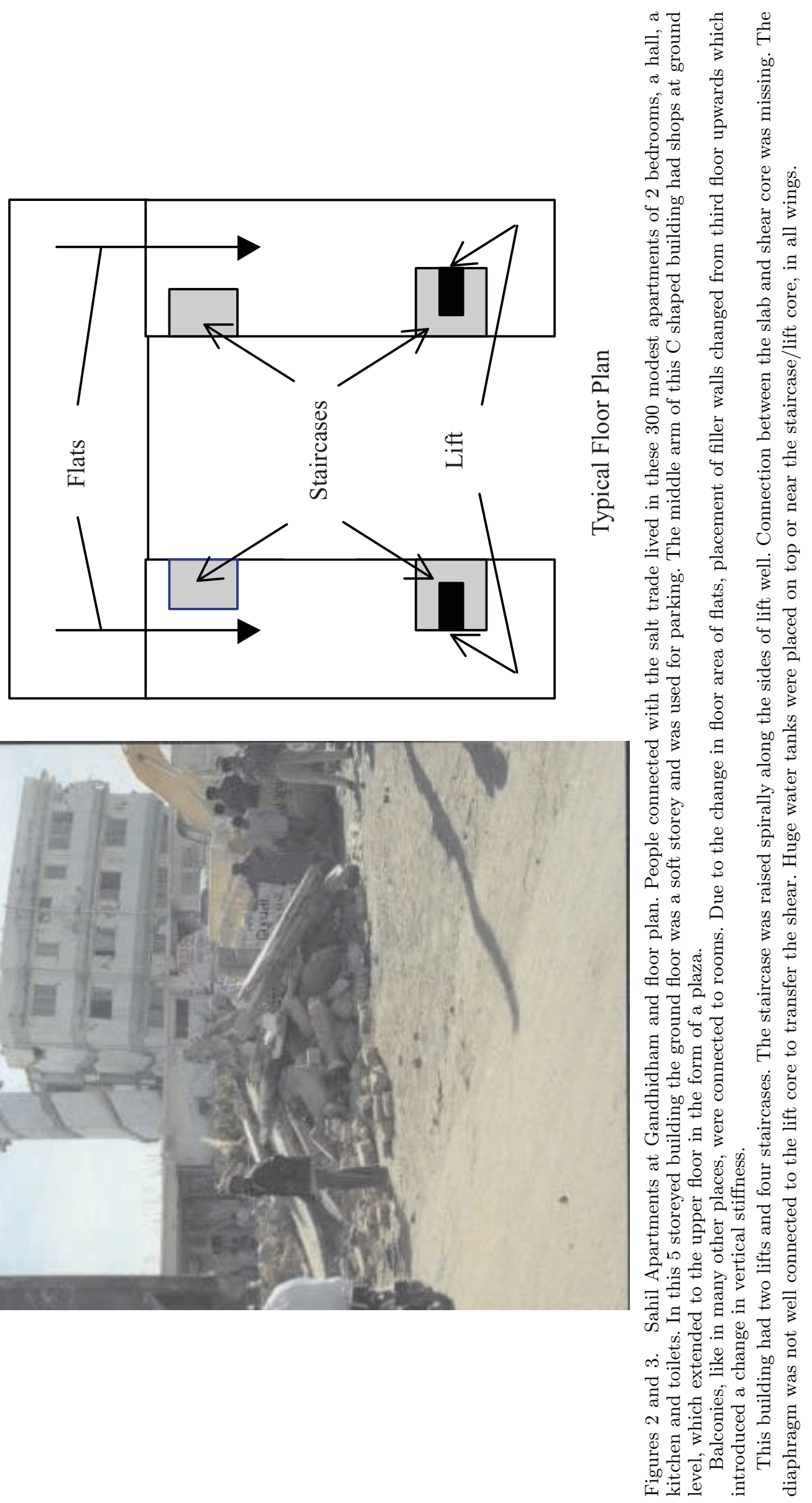
Table 3. Geographical coordinates of places marked in figure 1 and listed in table 2.

\begin{tabular}{|c|c|c|c|c|}
\hline $\begin{array}{c}\text { Map ID } \\
\text { no. }\end{array}$ & Place & $\begin{array}{c}\text { Longitude } \\
\text { o,", }\end{array}$ & $\begin{array}{c}\text { Latitude } \\
\circ, ",\end{array}$ & MMI \\
\hline 1 & Bhachau & 702033 & 231846 & $\mathrm{X}$ \\
\hline 2 & Samakhiali & 703020 & 231920 & $\mathrm{X}$ \\
\hline 3 & Rapar & 703835 & 233505 & $\mathrm{X}$ \\
\hline 4 & Manfara & 702058 & 233007 & $\mathrm{X}$ \\
\hline 5 & Chobari & 702042 & 233204 & $\mathrm{X}$ \\
\hline 6 & Adhoi & 703037 & 232451 & $\mathrm{X}$ \\
\hline 7 & Amardi & 701321 & 232105 & $\mathrm{X}$ \\
\hline 8 & Dudhai & 700731 & 232018 & $\mathrm{X}$ \\
\hline 9 & Kadol & 701652 & 232840 & $\mathrm{X}$ \\
\hline 10 & Kharoi & 702105 & 232802 & $\mathrm{X}$ \\
\hline 11 & Trambau & 703411 & 233601 & $\mathrm{X}$ \\
\hline 12 & Vondh & 702235 & 231910 & $\mathrm{X}$ \\
\hline 13 & Adesar & 705815 & 233349 & $\mathrm{X}$ \\
\hline 14 & Bhimasar (Rapar) & 700937 & 231244 & $\mathrm{X}$ \\
\hline 15 & Anjar & 700143 & 230807 & IX \\
\hline 16 & Ratnal & 695358 & 231232 & IX \\
\hline 17 & Santalpur & 711000 & 234500 & IX \\
\hline 18 & Surajbari bridge & 704040 & 231505 & IX \\
\hline 19 & Kukma & 694827 & 231414 & VIII \\
\hline 20 & Bhuj & 693959 & 231619 & VIII \\
\hline 21 & Madhapar & 694243 & 231536 & VIII \\
\hline 22 & Sukhpur & 693605 & 231410 & VIII \\
\hline 23 & Lodai & 695143 & 232629 & VIII \\
\hline 24 & Gandhidham & 700845 & 230356 & VIII \\
\hline 25 & Kandla & 701221 & 230245 & VIII \\
\hline 26 & Radhanpur & 694440 & 231903 & VIII \\
\hline 27 & Nakhtarana & 691503 & 232002 & VII \\
\hline 28 & Naliya & 685009 & 231605 & VII \\
\hline 29 & Khawda & 694303 & 235059 & VII \\
\hline 30 & Mandvi & 692201 & 225002 & VII \\
\hline 31 & Jamnagar & 700359 & 222759 & VII \\
\hline 32 & Halvad & 711101 & 230100 & VII \\
\hline 33 & Morvi & 705003 & 224903 & VII \\
\hline 34 & Ahmedabad & 725450 & 232509 & VII, VI \\
\hline 35 & Surendranagar & 714101 & 224204 & VI \\
\hline 36 & Viramgam & 720202 & 230659 & VI \\
\hline 37 & Rajkot & 705001 & 222002 & VI \\
\hline 38 & Gandhinagar & 724109 & 231258 & VI \\
\hline 39 & Surat & 730300 & 205500 & VI \\
\hline 40 & Vadodara & 732956 & 223002 & VI \\
\hline 41 & Broach & 725959 & 214504 & IV \\
\hline
\end{tabular}

\section{Figures 2 and 3 caption (Continued)}

Three storeys of a small portion of the building remained standing, seen in the photograph above, because of some partial attachment of stiff core of lift shaft to staircase. The lift shaft separated from the rest of the building. Torsion occurred due to discontinuity of horizontal and vertical configuration.

This RC framed structure suffered a damage of grade 5. This is a typical example where one should assign a low vulnerability class, in this case A (MSK-64 scale in IS 1893-2002), which represents an exceptionally low class for this type of structure. Poorly made structures in Gandhidham show similar damage and hence Gandhidham has been assigned intensity VIII.

Cranes and other heavy earth moving equipment were used to demolish the building. 300 bodies were already recovered from this area and four were taken out on third February, at the time of the visit. Two other similar buildings on the same street suffered the same fate. 
cially supported by the Delhi College of Engineering, Delhi for field visits. The authors were highly benefited by critical comments and discussions with Professors D K Paul, V H Joshi, Ashwani Kumar and H R Wason, and Drs. M L Sharma and J P Narayan, all from the Department of Earthquake Engineering, IIT Roorkee. The timely help rendered by Dr. A Gopalan, Director, Dr. S B Sharma, Dr. R P Prajapati, Sri Sanjeev Kulshretra and Sri Randhir Sethi of Space Application Centre, Ahmedabad, for providing the GPS and satellite data, is gratefully acknowledged. Personal discussions with Dr. S K Biswas, Sri James Peters and Sri Bhoj from ONGC, Dehradun, were of immense help in correlating field observations of damage with tectonics of the area.

The authors would like to place on record the help rendered by the people of the earthquakeaffected area, who despite their personal grief and misery offered help at the time of survey. Sri and Smt. A Mukerjee at Ahmedabad provided logistic support and helped in arrangements required for the damage survey. Ms. Madhulika Mukerjee and Sri Rajeev Shah, two student volunteers from the Centre for Environmental Planning and Technology, Ahmedabad, helped in the survey work.

\section{References}

Biswas S K and Deshpande S V 1983 ONGC Tectonic map of Kachchh, (Kutch), Geological map series no 1A, Scale 1:253440, ONGC, DehraDun.

Bose P R, Sinvhal A and Bose A 2001 Traditional construction and its behaviour in Kutch earthquake, p 151-158. In Proceedings of Workshop on Recent Earthquakes of Chamoli and Bhuj, May 24-26, 2001, Roorkee (eds) H R Wason, A K Pachauri and V Prakash; Ind. Soc. of Earthquake Technology, 551p

IS:1893-2002 (fifth revision) Indian Standard Criteria for Earthquake Resistant Design of Structures, Bureau of Indian Standards, New Delhi, India.

Prakash V, Sinvhal A and Bose P R 2001a Effects of the Kutch Earthquake of 26th January, 2001 on Oil Industry, p 159-165. In: Proceedings of Workshop on Recent Earthquakes of Chamoli and Bhuj, May 24-26, 2001, Roorkee (eds) H R Wason, A K Pachauri and V Prakash; Ind. Soc. of Earthquake Technology, 551p

Prakash V, Joshi V H, Wason H R and Sinvhal A 2001b Damage observed in temples, prayer halls and community centers due to the Kutch earthquake of 26th January, 2001, p 407-421. In: Proceedings of Workshop on Recent Earthquakes of Chamoli and Bhuj, May 24-26, 2001, Roorkee (eds) H R Wason, A K Pachauri and V Prakash; Ind. Soc. of Earthquake Technology, 551p

Prakash V, Joshi V H and Wason H R 2001c Effects of the Kutch earthquake of 26th January, 2001 on municipal overhead tanks, ground reservoirs and pumping units, p 433-441. In: Proceedings of Workshop on Recent Earthquakes of Chamoli and Bhuj, May 24-26, 2001, Roorkee (eds) H R Wason, A K Pachauri and V Prakash; Ind. Soc. of Earthquake Technology, 551p
Prakash V, Joshi V H and Wason H R 2001d Effects of the Kutch earthquake of 26th January, 2001 on Gujarat electricity board substations, p 443-449. In: Proceedings of Workshop on Recent Earthquakes of Chamoli and Bhuj, May 24-26, 2001, Roorkee (eds) H R Wason, A K Pachauri and V Prakash, Ind. Soc. of Earthquake Technology, 551p

Prakash V, Sinvhal A, Bose P R, and Bose A 2001e Effects of the Kutch earthquake of 26th January 2001 on lifeline structures. In: Abstract volume, International Conference on Seismic Hazard with Particular Reference to Bhuj Earthquake of January 26, 2001, 3-5 October 2001, IMD, New Delhi.

Prakash V, Sinvhal A and Bose P R 2001f Oil industry and the Kutch earthquake of 26th January 2001, p 175178. In: Abstract volume, International Conference on Seismic Hazard with Particular Reference to Bhuj Earthquake of January 26, 2001, 3-5 October 2001, IMD, New Delhi.

Saraf A K, Sinvhal A and Sinvhal H 2001 26th January 2001 Bhuj Earthquake: satellite data reveals earthquake induced ground changes and appearance of water bodies, p 207-215. In: Proceedings of Workshop on Recent Earthquakes of Chamoli and Bhuj, May 24-26, 2001, Roorkee (eds) H R Wason, A K Pachauri and V Prakash; Ind. Soc. of Earthquake Technology, 551p

Saraf A K, Sinvhal A, Sinvhal H, Ghosh P and Sarma B 2002 Satellite data reveals 26 January 2001 Kutch Earthquake induced ground changes and appearance of water bodies; International Journal of Remote Sensing 23 9, p 17491756

Sinvhal A, Bose P R, Prakash V, Bose A, Saraf A K and Sinvhal H 2001a Damage, seismotectonics and isoseismals for the Kutch earthquake of 26th January, 2001, p 6170. In: Proceedings of Workshop on Recent Earthquakes of Chamoli and Bhuj, May 24-26, 2001, Roorkee (eds) H R Wason, A K Pachauri and V Prakash; Ind. Soc. of Earthquake Technology, 551p

Sinvhal A, Bose P R, Bose A and Prakash V 2001b Damage observed to educational buildings due to the Kutch earthquake of 26th January, 2001, p 381-388. In: Proceedings of Workshop on Recent Earthquakes of Chamoli and Bhuj, May 24-26, 2001, Roorkee (eds) H R Wason, A K Pachauri and V Prakash; Ind. Soc. of Earthquake Technology, 551p

Sinvhal A, Bose P R, Bose A and Prakash V 2001c Damage observed to hospitals and medical facilities due to the Kutch earthquake of 26th January, 2001, p 389-397. In: Proceedings of Workshop on Recent Earthquakes of Chamoli and Bhuj, May 24-26, 2001, Roorkee (eds) H R Wason, A K Pachauri and V Prakash; Ind. Soc. of Earthquake Technology, 551p

Sinvhal A, Bose P R, Bose A and Prakash V 2001d Damage to railway bridge at Dholawa and railway station at Bhachau in Kutch earthquake of 26th January, 2001, p 399-406. In: Proceedings of Workshop on Recent Earthquakes of Chamoli and Bhuj, May 24-26, 2001, Roorkee (eds) H R Wason, A K Pachauri and V Prakash; Ind. Soc. of Earthquake Technology, 551p

Sinvhal A, Bose P R, Bose A and Prakash V 2001e Damage observed to Surajbari bridge due to the Kutch earthquake of 26th January, 2001, p 423-431. In: Proceedings of Workshop on Recent Earthquakes of Chamoli and Bhuj, May 24-26, 2001, Roorkee (eds) H R Wason, A K Pachauri and V Prakash; Ind. Soc. of Earthquake Technology, 551p

Sinvhal A, Bose P R, Prakash V, Bose A, Saraf A K and Sinvhal H 2001f Isoseismals for the Kutch earthquake of 26th January 2001, p 179-182. In: Abstract volume, Inter- 
national Conference on Seismic Hazard with Particular Reference to Bhuj Earthquake of January 26, 2001 3-5 October 2001, IMD, New Delhi.

Sinvhal A, Bose P R, Bose A and Prakash V 2001g Multistorey buildings and the Kutch earthquake of 26th January 2001, p 183-187. In: Abstract volume, International Conference on Seismic Hazard with Particular Reference to Bhuj Earthquake of January 26, 2001 3-5 October 2001, IMD, New Delhi.

Sinvhal A and Prakash V 2002 The Kutch earthquake of January 2001 and heritage buildings and monuments. In: Abstract Volume, Conference on Strategy and Methodology for Conservation of Heritage Buildings, CBRI, Roorkee, April 4-5, 2002. 